\title{
Clay Sorbents in the Area of the Most and Sokolov Basins as a Possible Use in Agriculture Reclamations
}

\author{
Petr Vráblík ${ }^{1}$, Michal Řehořㄹ, Pavel Schmidt² , Jaroslava Vráblíková1, Eliška Wildová1 \\ ${ }^{1}$ Department of Natural Sciences, Faculty of Environment, J. E. Purkyně University in Ústí nad Labem, Ústí nad Labem, \\ Czech Republic \\ ${ }^{2}$ Research Institute for Brown Coal in Most, Most, Czech Republic \\ Email: petr.vrablik@ujep.cz, rehor@vuhu.cz, schmidt@vuhu.cz, jaroslava.vrablikova@ujep.cz, Wildova.Eliska@gmail.com
}

How to cite this paper: Vráblík, P., Řehoř, M., Schmidt, P., Vráblíková, J. and Wildová, E. (2018) Clay Sorbents in the Area of the Most and Sokolov Basins as a Possible Use in Agriculture Reclamations. Agricultural Sciences, 9, 1621-1628.

https://doi.org/10.4236/as.2018.912113

Received: December 6, 2018

Accepted: December 24, 2018

Published: December 27, 2018

Copyright (C) 2018 by authors and Scientific Research Publishing Inc. This work is licensed under the Creative Commons Attribution International License (CC BY 4.0).

http://creativecommons.org/licenses/by/4.0/

\begin{abstract}
This paper is devoted to the possibilities of the reclamation use of claystone sorbents of the Most and Sokolov basins. The properties of phytotoxic areas suitable for the application of sorbents, the locality, and parameters of the main clay sorbents of both brown coal basins are briefly summarized in the paper. Clay sorbents are suitable for the reclamation of phytotoxic surfaces contaminated by coal. This paper provides a brief evaluation of the properties of the claystone sorbents of the North Bohemian and Sokolov basins. In the region of the North Bohemian brown coal basin, potential sorbents can be used for the reclamation works.
\end{abstract}

\section{Keywords}

Sorbents, Pedological Parameters, Reclamation, Contamination

\section{Introduction}

One of the major problems of reclamation work in the North Bohemian basin area is the reclamation of the areas contaminated by coal matter, and to a lesser extent with the mine waters and risky organic substances.

The occurrence of such areas is largely due to the development of coal seams. In the area of the Vršany quarry (splitting of the coal seam due to the Žatec delta) and Bílina mine (anomalous development of the coal seam), it may be assumed that an increased occurrence of debris in the coal seam. For this reason, phytotoxic areas containing a larger quantity of coal matter in the upper horizon often appear on the external and internal slopes of these mining sites. One can 
encounter problems with the acidic mine waters especially in the reclamation of the areas in the regions of the basin of the coal bed. The phytotoxicity of these sites is given, in addition to the increased sulfur content, especially with the extremely acidic soil reactions, and requires a specific reclamation methodology. The possibility of using claystone sorbents appears to be very promising.

This paper presents the characteristics of significantly phytotoxic areas, the prospective sites of claystone sorbents, and assesses the possibilities of their use in the reclamation works. The results are documented by monitoring the physical, mineralogical and chemical-pedological parameters of the claystone sorbents from the individual sites.

\section{Characteristic of the Phytotoxic Areas Occurring in the Area of the Most Basin}

Identified as phytotoxic areas in this contribution, are areas whose upper horizon is formed by rocks with very poor reclamation utilization. The properties of the rocks are so unfavorable that they do not allow the reclamation with conventional techniques. In this case, the use of reclamation additives is necessary. In the area of the North Bohemian basin, there are phytotoxic areas contaminated with coal matter (possibly with other risky organic substances), phytotoxic areas contaminated with acidic mine waters and sterile surfaces with the occurrence of plastic yellow clays at the upper horizon [1].

Phytotoxic areas contaminated by coal are the most prevalent. They are mainly found in the Bílina mine dump locations. Coal matter appearing in the upper horizon of the reclamation sites is a pollutant causing the phytotoxic nature of these areas. In particular, the cause is an extremely acidic soil reaction and high sulfur content. The use of fertilizable rocks is used to reclaim the sites, the optimal use of claystone sorbents. Some unusual reclamation additives, such as power system stabilizer [1] are also usable.

The phytotoxic areas contaminated by acidic mine waters are quite rare in reclaimed locations. In this case, the toxic nature is also caused by an extremely acidic soil reaction, a high sulfur content and coal matter. The reclamation of sites of this type involves the use of fertile rock combined with thoughtful drainage.

A specific type is areas with the appearance of plastic yellow clays in the upper horizon. They occur predominantly in the reclaimed sites of the Nástup-Tušimice mine. They can be characterized as sterile, the only unfavorable feature is an extremely heavy grain composition. Compost applications are usually used to reclaim sites of this type [2]. Methods based on the application of claystone sorbents are described in this paper.

\section{Overview of Claystone Sorbents in the Most and Sokolov Basins}

Clay sorbents are suitable for the reclamation of phytotoxic surfaces contami- 
nated by coal. This chapter provides a brief evaluation of the properties of the claystone sorbents of the North Bohemian and Sokolov basins, a closer description of bentonite deposits of the North Bohemian basin and zeolite deposits of the Sokolov Basin.

In the region of the North Bohemian brown coal basin, potential sorbents can be used for the reclamation work of the overlying kaolinitic-illitic claystone of the Libkov quarry, the montmorillonite overlay of the Libouš quarry, zeolites near the České středohoří, the tuftic positions of the coal bed and the bentonites of Černý vrch and Rokle. Analcime claystone from the Družba quarry and some tuftic positions from the same quarry were analyzed in the region of the Sokolov basin [3].

On the basis of the evaluation of this stage of the research, only montmorillonite supernatant claystone of the Libouš quarry, the bentonites of the Černý vrch and Rokle and the analcime claystone from the Družba quarry appear to be potentially useful.

\subsection{Bentonite Deposits in the North Bohemian Basin Region}

Bentonite deposits appear to be the most important natural clay sorbents in the North Bohemian basin. There are two significant deposists-Černý vrch and Rokle near Kadaň. The bentonite deposit in Černý vrch is the most important deposit in the North Bohemian Basin. The site is of tertiary volcano detritic origin. It is mainly made of clay tuff. There is a high-quality, bluish to bluish green bentonite in the deposit (especially on its basis). The extracted bentonite consists mainly of montmorillonite. The Rokle deposit consists of tuffs, tuffites, and tuffitic claystones. The main raw material in the deposit is bentonite suitable for foundry purposes. Its average thickness is about $24 \mathrm{~m}$.

\subsection{Characteristics of the Zeolite Claystone Deposits in the Sokolov Basin}

The deposit of the zeolite claystones at the Družba quarry is still the most important natural clay sorbent of the Sokolov basin. This is why they are given more attention in the paper.

The Družba mine is located in the eastern part of the Sokolov Basin. The underlying rocks are formed by granites of the Carlsbad massif, often intensely kaolinically weathered. The first stage of the basin's sedimentation consists of the Sokolov basin's Eocene geological formations. It is a variable set of diagonally layered, relatively well sorted, most probably river sediments of about $40 \mathrm{~m}$ thick, in places silicified. The second sedimentary stage is the volcano-sedimentary complex (Oligocene-the lower Miocene). At this stage, the sedimentation area of the Sokolov basin was created and the complex was deposited. The beginning of the coal sedimentation is the formation of the Josef seam (Oligocene-rupel). According to the new statigraphic classification [4] is included in the volcano-sedimentary complex. The volcano-detritic (rupel-eger) stack passes smoothly 
from the substrate without interrupting the sedimentation. Its thickness generally rises in an easterly direction. In the filling of the Sokolov basin, a wide range of rocks can be found, from purely poured and volcanoclastic to mixed laid sediments to sediments. The main brown coal formation (eggenburg) developed from the subsoil continuously without interruption of the sedimentation. The lowest coal bed of Anežka and the so-called middle soils in the region of the Družba quarry are not developed. The mine bed of Antonín is about $40 \mathrm{~m}$ thick. According to the new statigraphical classification of P. Rojík [4], the Miocene volcanoes and the main brown coal formation are merged into the Sokolov formation.

The cypris geological formation (Ottnang), named after Cypris angusta Reuss, nests on the Antonín coal bed concordantly, without hiatus but sharply. The lower part of the cypris formation is made up of kaolinitic clays. The upper part of the cypris formation consists of laminated claystones with a variable proportion of clay minerals of kaolinite, tri-mesh (illite, montmorillonite, nontronite) and quartzite (chlorite).

There is a deposit of zeolite claystones on the upper part of the cypris stack. Macroscopically, it is very difficult to distinguish it from cypris claystone. These are greenish-gray, often mild clays to claystone. In their mineralogical composition, the analcime, montmorillonite, quartz, kaolinite, and illite predominate, siderites and mica are often added. Zeolite analcime is in some cases the dominant mineral (Table 1). They are fine-grained rocks, which are characterized by excellent chemical-pedological properties and a very high absorption capacity, their reclamation efficiency is excellent [3].

The Cypris geological formation in the crosssections of the Družba quarry is shown in Figure 1.

\section{Possibilities of the Application of Claystone Sorbents When Reclaiming Phytotixic Areas}

The bentonites of the North Bohemian basin and the zeolite claystone of the Sokolov basin are optimal for the technical reclamation of phytotoxic surfaces because of their excellent absorptive abilities, very good chemical-pedological parameters and a suitable mineralogical composition. The obstacle preventing their wider use is the relatively high price of both the raw materials at present. Meanwhile, the only reclamation action in which the application of claystone sorbent on a large area was successfully utilized, is the reclamation of the Střimice dump. This reclamation project has already been described in detail in the

Table 1. Properties of the analcime claystone sample.

\begin{tabular}{|c|c|c|c|c|c|c|c|c|c|c|}
\hline \multirow{2}{*}{$\begin{array}{c}\text { Location } \\
\text { collection sample }\end{array}$} & \multirow{2}{*}{$\begin{array}{l}\mathrm{N} \\
(\%)\end{array}$} & \multirow{2}{*}{$\begin{array}{l}\text { Cox } \\
(\%)\end{array}$} & \multirow{2}{*}{$\begin{array}{c}\mathrm{CaCO}_{3} \\
(\%)\end{array}$} & \multirow{2}{*}{$\begin{array}{c}\mathrm{pH} \\
/ \mathrm{H}_{2} \mathrm{O}\end{array}$} & \multicolumn{3}{|c|}{$\begin{array}{c}\text { Acceptable nutrients } \\
\left(\mathrm{mg} \cdot \mathrm{kg}^{-1}\right)\end{array}$} & \multicolumn{3}{|c|}{$\begin{array}{c}\text { Absorption capacity } \\
\text { mmol (\%) }\end{array}$} \\
\hline & & & & & $\mathbf{P}$ & K & $\mathrm{Mg}$ & $S$ & $\mathrm{~T}$ & $\mathrm{~V}$ \\
\hline Družba quarry & 0.01 & 0.5 & 4.6 & 7.8 & 5 & 386 & 1234 & 32 & 32 & 100 \\
\hline
\end{tabular}




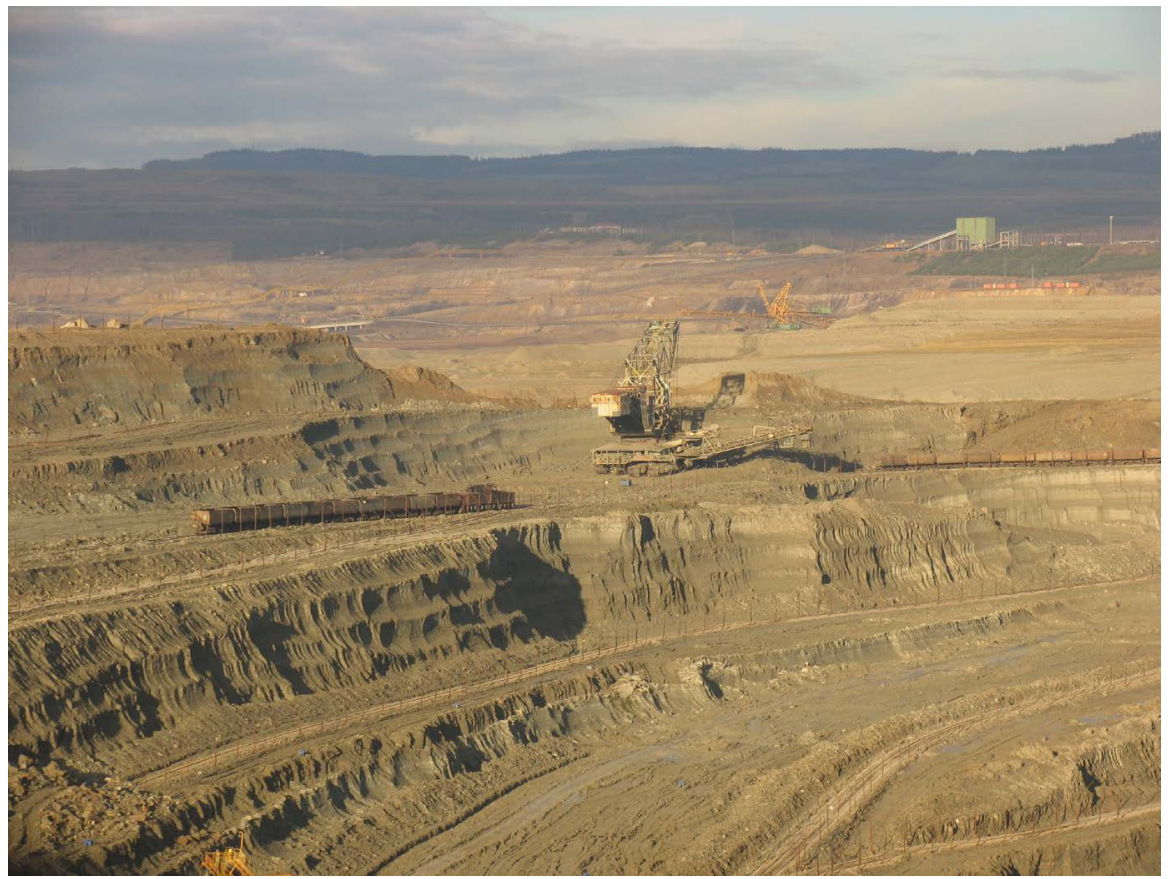

Figure 1. Excavated cross-sections of the Družba mine.

Brown Coal Newsletter [5], so it is only briefly mentioned here. The dump is located north-east of Most. It was made between 1959 and 1973. The surface area of the dump is 160 hectares and the altitude reaches 330 meters above sea level. The original forest reclamation was carried out in 1967. Due to adverse changes in the surface area of the dump, planting has virtually ceased. At the same time, the influence of erosion phenomena was significant. Technical reclamation was used for reclaiming the bentonite from the Černý vrch mine. The layer of bentonite soil weighed out was set at $50 \mathrm{~cm}$. After plowing and grassing, afforestation was later performed. Subsequently, agricultural reclamation was commenced on the surface of the dump with a total area of 89 ha. Reclamation of the location in Strimice is now completed. At the top of the dump, there is an airport with an area of approximately 90 ha, which is surrounded by agricultural land reclamation. A forest reclamation with hiking trails was done on the slopes of the dump. In addition, today the site provides a unique opportunity to monitor the development of the anthropogenic soil profile. The montmorillonite claystone of the Libouš quarry does not reach the quality of bentonite and zeolite claystones. However, they are usable in the reclaimed sites of Severočeské doly a.s. where, in the case of the occurrence on the surface of the field, they allow the direct forest reclamation without applying other fertilizable soils.

\section{Other Possibilities of Research on Clay Sorbents}

Possible further research work would continue the research done so far. The actual research work would be preceded by an evaluation of the results obtained so far. Then, the six main stages of research would follow. This involves mapping of 
other potentially prospective sites including collection of samples and their analysis, inventory of bentonite and zeolite claystones, research of their reclamation utilization on model experimental surfaces, chemical absorption of bentonites and zeolite claystones on model solutions, the chemical absorption tests of bentonites and zeolite claystones on contaminated waters of the individual sites and researching the possibilities of these sorbents in the redeveloping of landfills.

Mapping of promising locations, including the sampling and analysis of samples

The geological mapping of the overburden cross sections of the surface mines and the wider areas of the existing bentonite mines to date has been carried out in the research phase. Therefore, further work is focused on the upper horizon of the previously uncultivated dump sites, abandoned quarries, and promising outposts. Samples will be taken at the mining sites, quarries and outcrops and on the sample dumps using the probe bar. The aim will be to find all the bentonite and zeolite claystone sites in both the brown coal basins. Of primary importance is assessing the quality of bentonites and zeolite claystones, the absorption capabilities, including sorbent tests on the contaminated water, montmorillonite content, and zeolites. However, due to the anticipated use of the raw material, a broader range of analysis will be carried out.

- performing grain sample analyzes

- performing mineralogical analysis of the samples

- Performing chemical-pedological analysis of the samples (soil reaction, Cox,

$\mathrm{CaCO}_{3}$ content, $\mathrm{S}$ content, nitrogen content, absorption S, T, V, the content of acceptable nutrients $\mathrm{P}, \mathrm{K}, \mathrm{Mg}$ )

- determining the content of hazardous trace elements within the scope of the Decree of the Ministry of the Environment No. 13/94 Coll.

- determining the content of non-polar extractable substance or other hydrocarbons

- permeability tests

Determining reserves of virtually usable bentonites, and zeolite claystones

On the basis of the results of mapping and laboratory analyses, new potential deposits of these raw materials will be delimited, their maps will be drawn up and their stocks will be determined. Computer modeling methods will be used during the work.

Research on the reclamation utilization of bentonites, and zeolite claystones on model experimental surfaces

In the reclaimed areas of the North Bohemian and Sokolov basins, small experimental sites will be set up to which bentonites and zeolite claystones from the various locations found in the previous stages of the research will be applied. Different amounts of sorbents will be applied to different locations. On the basis of sampling, the development of the soil horizon will be investigated. Previously established experimental areas will be used for the research, for which bentonite 
from Černý vrch and Rokle were applied.

\section{Absorption tests of bentonite and zeolite claystones on model solutions}

At the VSB-Technical University of Ostrava workplace, model solutions will be prepared to include a whole range of anticipated contaminated water. These solutions will be tested for the absorption of bentonite and zeolite claystones from the individual sites. Tests for the absorption properties of the modified smectite forms will be performed

Tests of the absorption of bentonites and zeolite claystones on the contaminated waters from the individual sites

Samples of the contaminated waters will be collected from the sites of Obránci míru, Radvanice, Kutná Hora, Př́bram and Zlaté Hory. Tests of the absorption of bentonites and zeolite claystones from the individual sites will be carried out on the water from these sites. Tests for the absorption properties of the modified smectite forms will be performed. On the basis of the results, the possibilities of application of the individual rock types at these sites will be assessed.

\section{Preparation of the modified smectite forms}

Modifications of the smectites will go in two directions. In the natural forms of the smectites, the interlayer is occupied together by monovalent $\left(\mathrm{Na}^{+}, \mathrm{K}^{+}\right)$and divalent $\left(\mathrm{Ca}^{2+}, \mathrm{Mg}^{2+}\right)$ cations. The type of the predominant interlayer cation affects the properties and hence its usefulness. Therefore, in many applications, it is advantageous to have the interlayer positions occupied by only one type of cation. Thus, the first of the research studies of the modifications will focus on the possibility of transferring the Czech smectite to monoionic forms. The second of the modifications will then be focused on the intercalation of smectites. The second of the modifications will then be focused on the intercalation of smectites (intercalation with organic molecules and with inorganic polycations).

\section{Conclusions}

The aim of this paper is to characterize the phytotoxic surfaces of the North Bohemian basin with a focus on the possibilities of their reclamation. The reclamation methods using the application of claystone sorbents are characterized here and the utilization of sorbents from the individual sites.

Potential clay sorbents were characterized by kaolinitic-illitic claystone of the Libkovice formation, montmorillonite overlay claystone, bentonites and claystone, with the greatest emphasis being placed on the bentonites of the North Bohemian basin and the analytical claystone. This contribution describes the occurrence of these rocks, their brief characteristics and their possible application in the reclamation process. The experience gained from the only extensive application of the claystone sorbent on the Strimice dump is also presented here.

\section{Acknowledgements}

This article was supported by project QJ1520307 entitled "Sustainable Forms of Management in an Anthropogenically Burdened Region.” This project was real- 
ized with financial support from state budget resources through the KUS program, Ministry of Agriculture of the Czech Republic.

\section{Conflicts of Interest}

The authors declare no conflicts of interest regarding the publication of this paper.

\section{References}

[1] Rojík, P. (2005) Miocene Volcanoes in the Sokolov Basin. Zpravodaj Hnědé uhlí, 2/2005, s. 16-34, Research Institute for Brown Coal, Most.

[2] ¿̌ehoř, M., Šafářová, M. and Ondráček, V. (2004) Application of Some Coal Treatment Products for Reclamation of Localities in the North Bohemian Basin. 21 st Pittsburg Coal Conference, Osaka, 13-17 September 2004, 15-16.

[3] Řehoř, M., Šafářová, M. and Lang, T. (2004) History, the Present and Perspectives of the North Bohemian Brown Coal Basin Area Reclamation. 4th International Scientific Conference SGEM, Albena, 14-18 June 2004, 220-228.

[4] Řehoř, M. (2005) Mineralogical Research of Organic Matter in Extracted Seams and Selected Deposits in Their Overburden, incl. Assessment of Potential Accompanying Raw Materials at Sokolov Mining Company Sites. Expert Review, Research Institute for Brown Coal, Most.

[5] Řehoř, M., Ondráček, V. and Lang, T. (2006) Methodology of Reclamation of Different Habitat Types in SHP Spoil Tip Sites-Partial Results of a Research. Zpravodaj Hnědé uhlí, 2/2006, s. 7-17, ISSN 1213-1660, Research Institute for Brown Coal, Most. 